\title{
Chapter 10 \\ Relevance and Quality of Climate \\ Planning for Large and Medium-Sized \\ Cities of the Tropics
}

\author{
Maurizio Tiepolo
}

\begin{abstract}
In the last seven years, the number of plans with climate measures for tropical cities has increased 2.3 times compared to the previous seven years as a result of the initiatives of central and local governments, multi-bilateral development aid and development banks. The plans matter in achieving the 11th United Nations' Sustainable development goal. Therefore, the objective of this chapter is to ascertain the relevance and quality of climate planning in large and medium-sized cities in the Tropics. The chapter proposes and applies the QCPI-Quality of Climate Plans Index, consisting of 10 indicators (characterization of climate, number, quantification, relevance, potential impact, cost, funding sources, timetable and responsibility of measures, implementation monitoring and reporting). It is revealed that 338 tropical cities currently have a local development, emergency, master, mitigation, adaptation, risk reduction plan or a resilience or smart city strategy. These tools were unquestionably more common in large cities, especially in OCDE and BRICS countries, while they were rare in Developing Countries. Local development plans (Municipal development, general, comprehensive) were the most common in medium-sized cities, along with those with the lowest quality, while stand-alone strategies and plans (resilience, mitigation, sustainable, adaptation), applied mostly in big cities, present much higher quality.
\end{abstract}

Keywords Climate change - Municipal development plan - Master plan • Emergency plan - Mitigation plan - Adaptation plan - Risk reduction plan • Resilience strategy $\cdot$ Smart city $\cdot$ Plan quality $\cdot$ Tropics

\footnotetext{
M. Tiepolo ( $\square)$

DIST, Politecnico and University of Turin, Viale Mattioli 39, 10125 Turin, Italy

e-mail: maurizio.tiepolo@polito.it 


\subsection{Introduction}

Climate plans are used by a growing number of cities to reduce the emission of Green House Gases (GHG) into the atmosphere (mitigation, sustainable action plans) and the impacts of climate change (emergency, adaptation, risk reduction, resilience plans). Municipal development and master plans should also be considered among climate plans when they contain measures aimed at altering the urban spatial configuration, density, land cover and physical building characteristics, all factors that can modify the urban micro climate (Alcoforado and Matzarakis 2010).

In the Tropics, climate plans began to be developed in around 2003, based on the initiatives of several multilateral bodies (development banks, United Nations), bilateral aid, associations and movements of local governments (ICLEI-International Council for Local Environmental Initiatives, C40), certain foundations (Rockefeller, Bloomberg), and commitments made by individual countries within the framework of international agreements (UN Framework Conference for Climate Chance, Hyogo Framework for Action). These commitments are often converted into national laws that enforce local climate planning.

One of the recurring topics of the debate on climate planning is which tools to use to plan the reduction of GHG emissions and the impacts of CC on cities: stand-alone plans or mainstreaming of climate measures in existent plans (UN-Habitat 2009, 2011, 2015). According to Aylett (2014), climate planning is not achieved with isolated plans. This said, the mainstreaming of climate measures requires the existence of plans which, according to Fraser and Lima (2012), are absent in small towns.

A second topic is the quality of plans. Until a few years ago, according to the results of the surveys carried out by Wheeler (2008), Tang et al. (2010) and Preston et al. (2011), the quality was rather low. The first quality factor is the solidity of the preliminary analysis that precedes planning. According to Hunt and Watkiss (2011), it was very imbalanced in relation to flood risk. Another quality factor concerns measures. According to Buckley (2010) and Anguelowski and Carmin (2011), those for mitigation of emissions prevail over those for adaptation to impacts. Among the measures envisaged, those effectively applied are only the short-medium term ones, those that can be accomplished within the space of a mandate (Lethoko 2016). Wheeler (2008) then found that, in the United States, the measures envisaged by climate action plans were insufficient to significantly reduce GHG emissions.

The above information is taken from surveys with a rather varied reach: from a few case studies (Vergara 2005; UN Habitat 2015) to a few hundred cities (Carmin et al. 2012; CAI 2012; CDP 2014) without distinguishing between towns and mega cities, tropical, sub-tropical or boreal settlements, least-developed countries and wealthiest economies. Carried out in this way, these surveys do little to help identify the points on which to strengthen climate planning. To find a remedy for this absence, in 2015 we investigated two climatic zones (Sub-tropics and Tropics), a specific class of city (large), concentrating attention only on stand-alone plans (Tiepolo and Cristofori 2016). It turned out that climate planning was still rather 
scarce (24\% of cities) despite being on the increase $(+1.5$ times in the last five years). Emergency, mitigation, adaptation and resilience plans were, in that order, the most widespread in big cities but quality was poor in $70 \%$ of cases. The results of that survey looked promising. This is why, in 2016, we extended the survey to medium-sized cities and to all the existing plans, but narrowed observation to the Tropics only, where there was a higher concentration of Developing Countries (DCs) and Least-Developed Countries (LDCs).

This chapter aims to ascertain (i) the relevance of climate planning and (ii) its quality. The methodology followed starts with the identification of the cities that are populated by over 0.1 million inhabitants (1388) in tropical zone and then, among these, those that have enforced climate a planning tool (338). This is followed by the download of the plans and the construction of the database. Lastly, the analysis: types of plans, their relevance (by class of city, by country and economy), and quality, through the specially conceived QCPI-Quality of Climate Plans Index. The following paragraphs are going to look at the methodology, the results (rise of climate planning in the Tropics, planning categories, quality), discussion, conclusions (focusing on possible improvements in climate planning and on recommendations to put them into practice).

\subsection{Materials and Methods}

This chapter is based on the results of a survey on climate plans in Chinese, English, French, Portuguese and Spanish, for cities with over 100,000 inhabitants, in 95 tropical countries. The survey covers $63 \%$ of tropical cities, while the remaining $37 \%$, which belongs to countries from other linguistic areas (especially Philippines, Indonesia, Malaysia, Bangladesh and Viet-Nam), is covered on a limited basis by plans accessible in English. The term big cities refers to jurisdictions with over one million inhabitants. Medium-sized cities are administrative jurisdictions with a population of between 0.1 and 1 million people. Some big cities are split into municipalities. If these jurisdictions have over 100,000 inhabitants and have a plan, like those of Lima, Miami, Niamey, Phoenix, Port-au-Prince, Rio de Janeiro, Santo Domingo and Yaoundé, then they were considered.

The plans were identified on the websites of the municipalities. Unavailable open access plans were excluded from the survey.

The tropical zone was defined with Köeppen-Geiger's classification based on temperatures and rainfall observed over the period 1971-2000 (Rubel and Kottok 2010) on a $0.5^{\circ}$ latitude/longitude regular grid, as presented on the website http:// koeppen-geiger.wu-wien.ac.at/shifts.htm. Categories and subcategories were used according to Trewartha's classification (Belda et al. 2014), which is adopted by the FAO, the Joint Research Centre of the European Commission and by IPCC (www. fao.org/docrep006/ad6528/ad652e07.htm). The tropical zone includes the categories wet-tropical rain forest and tropical wet in dry called savanna. A city is considered tropical if at least part of it is included in the tropical climatic grid. For 
cities on the edges of the climatic zone of interest, the built-up area was recognized on Google Earth. In addition to the demographic class, cities with a climate plan were divided by economy: OECD (Australia, overseas French jurisdictions, Mexico and USA) and Singapore, BRICS (Brazil, India, China and South Africa), DC-Developing Countries (23 countries), LDC-Least Developed Countries (9 countries). All the measures for the reduction of emissions and adaptation to CC were registered (123 for medium-sized cities and 147 for big ones). When we had finished, we had created a database with 53,000 data items containing 355 types of information.

We created a specific QCPI-Quality of Climate Plans Index to assess the action driven nature and the potential impact of climatic plans. The index gathers 10 indicators (climate characterization, number, quantification, relevance, potential impact, cost, funding sources, timetable and responsibility for each measure, implementation monitoring and reporting) (Table 10.1). Every indicator is assigned an equal weight (1 point).

The value of the QCPI can, therefore, vary between 0 and 10. In identifying the indicators, we referred to previous works which had examined plan quality (Baer 1997; Norton 2008) and reduced the number of indicators to effectively succeed in measuring them in a high number of plans often very different from one another. The indicator of potential impact refers the existence in every plan of at least one of the mitigation measures susceptible for significantly reducing emissions of $\mathrm{CO}_{2}$ or for reducing the hydro-climatic risk according the mitigations plans of Belo Horizonte, Fortaleza, Miami and Phoenix (Table 10.2). It is not possible to appreciate the degree of implementation of the plans through this survey, as the municipalities rarely publish annual monitoring reports on this matter.

Table 10.1 Description of the indicators used for the QCPI

\begin{tabular}{l|l}
\hline Indicators & Concept \\
\hline $\begin{array}{l}\text { 1. Climate } \\
\text { characterization }\end{array}$ & Local climate trends and changes expected over the next 20 years \\
\hline $\begin{array}{l}\text { 2. Number of measures } \\
\text { 3. Quantification of } \\
\text { measures }\end{array}$ & Plans with over 10 climatic measures \\
\hline \begin{tabular}{l} 
4. Relevance of measures \\
Specification of the quantity of each measure \\
\hline 5. Potential impact
\end{tabular} & Estimated impact of any measure on emissions or risk \\
\hline 6. Cost of measures & Estimated cost of each measure \\
\hline 7. Funding & Specification of the funding sources for each measure \\
\hline 8. Responsible & $\begin{array}{l}\text { Specification of the structure responsible for implementing each } \\
\text { measure }\end{array}$ \\
\hline $\begin{array}{l}\text { 9. Monitoring \& } \\
\text { Reporting }\end{array}$ & Description of the monitoring and reporting system \\
\hline 10. Timetable & Distribution of measures over time \\
\hline
\end{tabular}


Table 10.2 Soundness of measures in climate plans for big and medium-sized tropical cities

\begin{tabular}{l|l|l}
\hline Sector & Measure & Potential reduction of $\mathrm{CO}_{2}$ emissions \% \\
\hline Mitigation & Less polluting fuels & $0.9-7.5$ \\
\hline & Bike/car sharing & 1 \\
\hline & LED street lighting & 2 \\
\hline & Green roof & 3 \\
\hline & LEED Certification & $2-3$ \\
\hline & RRR waste & $1-2.1$ \\
\hline & Solar in buildings & 5.3 \\
\hline & Subway & 4 \\
\hline & BRT & $5.7-8$ \\
\hline & Methane capture (landfill) & 20 \\
\hline & Renewable energy & 33 \\
\hline Adaptation & Waste water reuse & 33 \\
\hline & Resettlement & 100
\end{tabular}

\subsection{Results}

\subsubsection{Relevance of Climate Planning in the Tropics}

Reducing the impact of $\mathrm{CC}$ entails (i) reducing the causes, (ii) protecting the population and assets exposed both before and (iii) during a hydro-meteorological or climate-related disaster.

Usually, the local governments plan these activities as the application of specific national or regional laws, as in the case of Colombia, Mexico, Niger, Philippines, etc. In the remaining cases, they do so after signing the US Conference of Mayors' Climate Protection Agreement (2005), the C40 or other unilateral initiatives to reduce the risk.

In the Tropics, today, at least 338 cities in 41 countries have a climate plan (Table 10.3; Figs. 10.1 and 10.2). This is almost a quarter of the cities. The highest number $(79 \%)$ is in the OCDE countries, followed by BRICS (49\%), LCDs (35\%) and DCs (just 22\%).

Since 2010, the number of climate plans has increased 2.3 times the number produced during the previous seven years (Fig. 10.3). In 2012, climate plans

Table 10.3 Tropical cities provided with climate plan

\begin{tabular}{l|l|l|l}
\hline Tropical cities (class) & a & b & a/b * 100 \\
\hline & with climate plan & all & \\
\hline Big, > 1MP & 65 & 166 & 39 \\
\hline Medium, 0,1-1 MP & 273 & 1222 & 22 \\
\hline Big and medium & 338 & 1388 & 24 \\
\hline
\end{tabular}




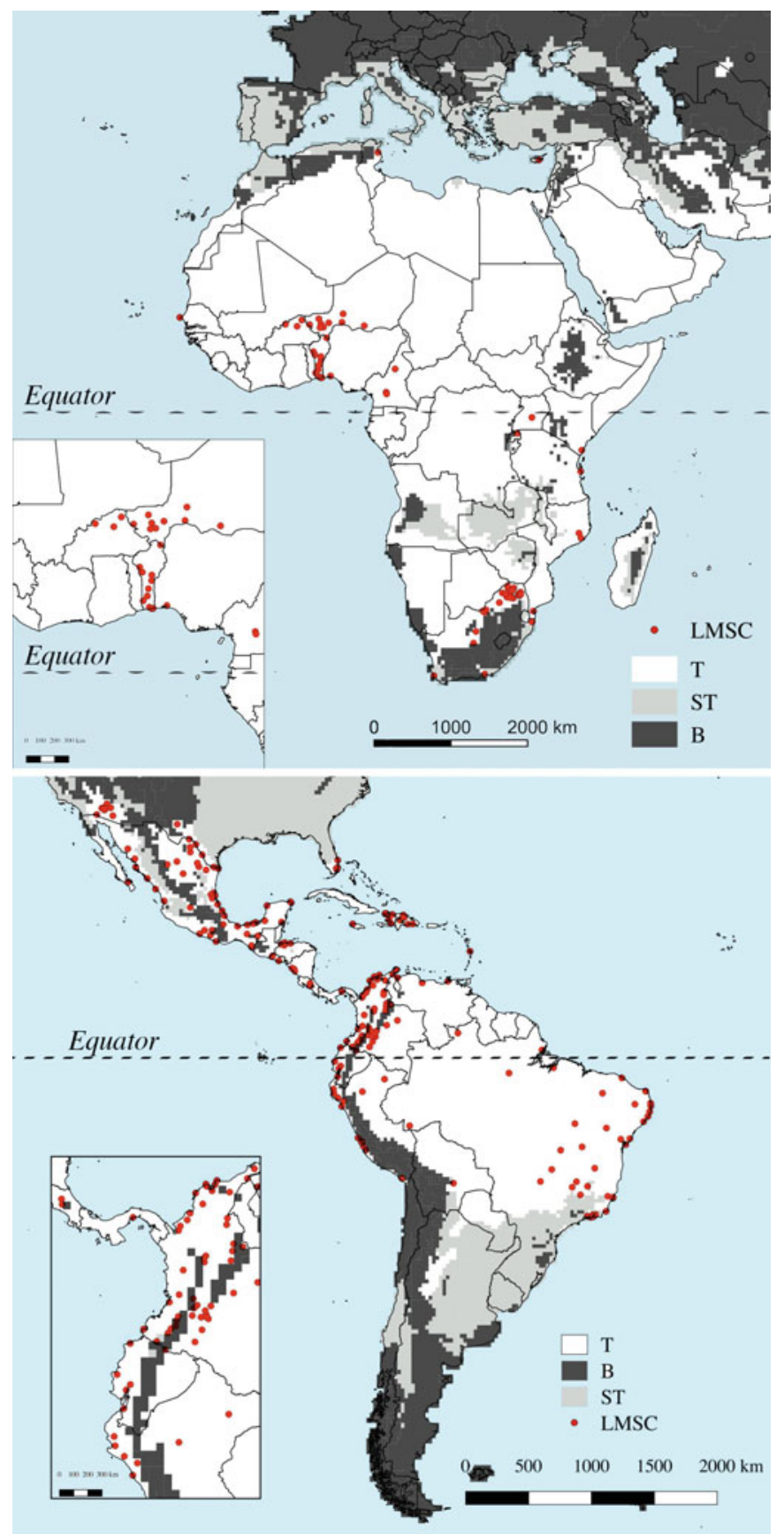

Fig. 10.1 Big and medium-sized cities of Tropical $(T)$ Africa an Latin America provided with climate plan 


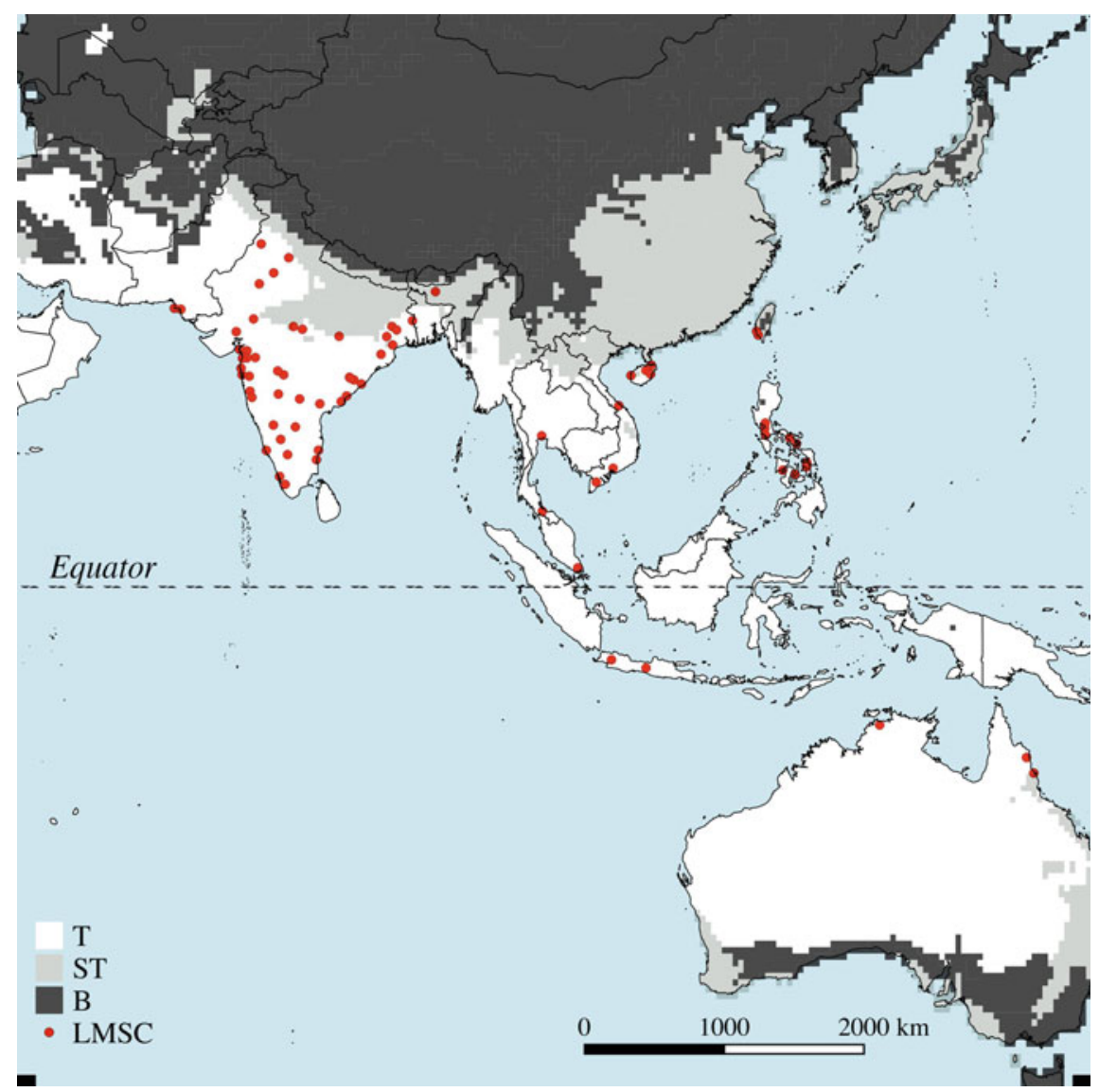

Fig. 10.2 Big and medium-sized cities of Tropical $(T)$ Asia provided with climate plan

suddenly increased, following the entry into force of national legislations (Colombia and Mexico) which required the consideration of risk in municipal development plans (MDPs). Nevertheless, cities with climate plans in the Tropics are half those in the Sub-Tropics (Tiepolo and Cristofori 2016).

In 13 countries, climate planning is practiced by over half the cities (Table 10.4).

\subsubsection{Plan Categories}

Climate plans unite numerous tools, which sometimes have no equivalents in countries belonging to different linguistic areas (Table 10.5).

Municipal development plans are the most common tools (44\%), followed by master plans $(13 \%)$, emergency plans $(12 \%)$, sustainable action and mitigation 


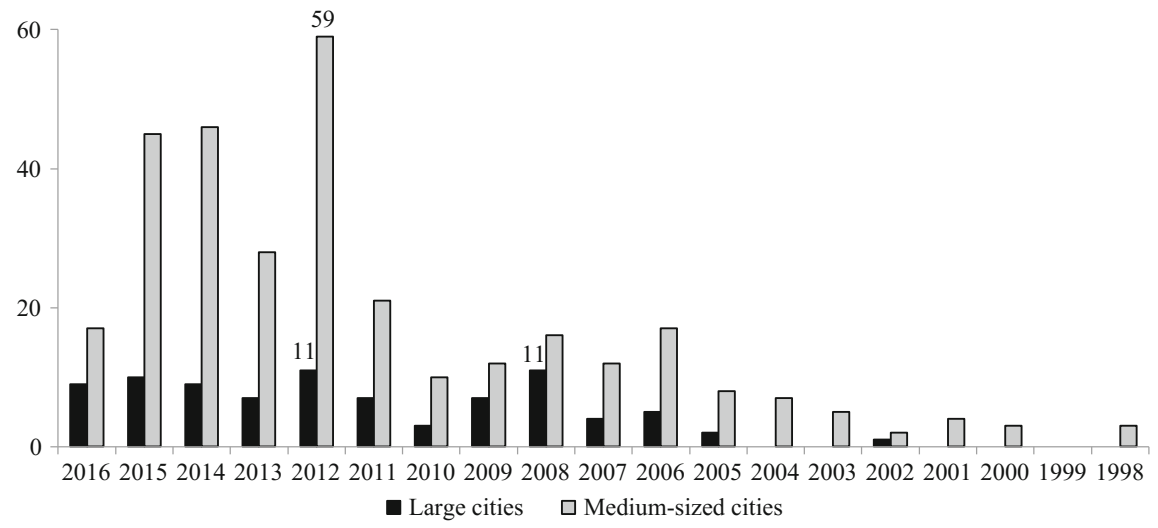

Fig. 10.3 Climate plans for big and medium-sized tropical cities by year of implementation

Table 10.4 Countries with greater relevance of climatic planning in the tropical zone

\begin{tabular}{l|l|l|l|l|l|l|l|l|l|l}
\hline \multirow{2}{*}{ Country } & \multicolumn{3}{l}{ Big cities } & \multicolumn{3}{l}{ Medium-sized cities } & \multicolumn{3}{l}{$\begin{array}{l}\text { Big-medium-sized } \\
\text { cities }\end{array}$} \\
\cline { 2 - 12 } & Total & With plan & Total & \multicolumn{2}{l}{ With plan } & Total & \multicolumn{2}{l}{ With plan } \\
\cline { 2 - 12 } & $\#$ & $\#$ & $\%$ & $\#$ & $\#$ & $\%$ & $\#$ & $\#$ & $\%$ \\
\hline Australia & 0 & 0 & 0 & 3 & 3 & 100 & 3 & 3 & 100 \\
\hline Benin & 0 & 0 & - & 8 & 8 & 100 & 8 & 8 & 100 \\
\hline Costa Rica & 0 & 0 & 0 & 2 & 2 & 100 & 2 & 2 & 100 \\
\hline Honduras & 1 & 1 & 100 & 5 & 5 & 100 & 6 & 6 & 100 \\
\hline Peru & 2 & 2 & 100 & 13 & 13 & 100 & 15 & 15 & 100 \\
\hline Rwanda & 1 & 1 & 100 & 0 & 0 & 0 & 1 & 1 & 100 \\
\hline Singapore & 1 & 1 & 100 & 0 & 0 & 0 & 1 & 1 & 100 \\
\hline USA & 2 & 2 & 100 & 20 & 20 & 100 & 22 & 22 & 100 \\
\hline South Africa & 0 & 0 & 0 & 29 & 28 & 97 & 29 & 27 & 97 \\
\hline Colombia & 5 & 5 & 100 & 45 & 38 & 84 & 50 & 43 & 86 \\
\hline Brazil & 14 & 11 & 79 & 42 & 31 & 74 & 56 & 42 & 75 \\
\hline Mexico & 1 & 0 & 0 & 60 & 45 & 73 & 61 & 45 & 74 \\
\hline Nicaragua & 1 & 1 & 100 & 6 & 3 & 50 & 7 & 4 & 57 \\
\hline Taiwan & 2 & 2 & 100 & 2 & 0 & 0 & 4 & 2 & 50 \\
\hline
\end{tabular}

plans (12\%), risk reduction plans (8\%), smart city proposals (4\%), adaptation plans (3\%), resilience strategies (2\%) and other types of plans (2\%) (Table 10.6).

Sixteen cities have both a mitigation/adaptation or resilience plan, as well as an emergency or risk reduction plan.

Big cities use a broad range of tools: municipal development plans (21\%), mitigation plans (17\%), emergency plans (13\%) and smart city proposals (13\%) and 
Table 10.5 How to say climate plan in English, Spanish, French and Portuguese speaking countries. Asteriscs show long term plans

\begin{tabular}{|c|c|c|c|}
\hline English & Spanish & French & Portuguese \\
\hline $\begin{array}{l}\text { Comprehensive } \\
\text { development* } \\
\text { Integrated } \\
\text { development* } \\
\text { General plan* }\end{array}$ & $\begin{array}{l}\text { P. desarollo } \\
\text { communal/municipal/local } \\
\text { concertado, P. territorial } \\
\text { desarollo integral }\end{array}$ & $\begin{array}{l}\text { P. développement communal, } \\
\text { P. investissement communal, } \\
\text { P. développement strategique }\end{array}$ & \\
\hline $\begin{array}{l}\text { Contingency p. } \\
\text { Emergency p. } \\
\text { Crisis } \\
\text { management p. }\end{array}$ & $\begin{array}{l}\text { P. contingencia } \\
\text { P. emergencia, PLEC }\end{array}$ & P. contingence & P. contingência \\
\hline $\begin{array}{l}\text { Climate action } \\
\text { p. }\end{array}$ & $\begin{array}{l}\text { Plan accion climatica } \\
\text { municipal }\end{array}$ & Plan climat energie territoire & $\begin{array}{l}\text { Ação e metas } \\
\text { para a redução de } \\
\text { Gases de Efeito } \\
\text { Estufa }\end{array}$ \\
\hline \multicolumn{4}{|l|}{ Smart city } \\
\hline \multicolumn{4}{|l|}{$\begin{array}{l}\text { Recovery \& } \\
\text { rehabilitation }\end{array}$} \\
\hline $\begin{array}{l}\text { Sustainable } \\
\text { action p. } \\
\text { S. development } \\
\text { strategy }\end{array}$ & & & $\begin{array}{l}\text { P. ação } \\
\text { sustentável }\end{array}$ \\
\hline \multicolumn{4}{|l|}{$\begin{array}{l}\text { Resilience } \\
\text { action p. }\end{array}$} \\
\hline $\begin{array}{l}\text { Disaster } \\
\text { management p. }\end{array}$ & $\begin{array}{l}\text { P. municipal gestión riesgo } \\
\text { desastre }\end{array}$ & & $\begin{array}{l}\text { P. municipal de } \\
\text { redução do risco }\end{array}$ \\
\hline \multicolumn{4}{|l|}{ Adaptation p. } \\
\hline Green print & Estrategico & & \\
\hline \multicolumn{4}{|l|}{$\begin{array}{l}\text { Environment } \\
\text { resources } \\
\text { management }\end{array}$} \\
\hline $\begin{array}{l}\text { Master p. } \\
\text { City p. }\end{array}$ & $\begin{array}{l}\text { P. directeur d'urbanisme, } \\
\text { P. local d'urbanisme }\end{array}$ & & P. diretor \\
\hline Land use $\mathrm{p}$. & & & $\begin{array}{l}\text { P. de } \\
\text { ordenamiento } \\
\text { territorial }\end{array}$ \\
\hline
\end{tabular}

\footnotetext{
* Long term plans
}

emergency plans (13\%). Medium-sized cities, on the other hand, use municipal development plans $(50 \%)$, master plans $(15 \%)$ or risk reduction plans $(9 \%)$.

\section{Municipal Development, General and Compehensive Plans}

These are the most popular plans (44\%). They organize the measures for every area of jurisdiction of local administration: transportation, infrastructure, housing, land use, conservation, economic development, education, healthcare. Municipal Development Plans (MDP) are medium term tools, that define actions within the space of a mandate (4-5 years). General and comprehensive plans, common in the 
Table 10.6 Types of climate plan for big and medium-sized tropical cities

\begin{tabular}{l|l|l|l|l|l|l}
\hline \multirow{2}{*}{ Type of plan } & \multicolumn{2}{l}{ Climate plans for cities } & \multicolumn{4}{l}{$l$} \\
\cline { 2 - 7 } & Big/medium-sized & Big & n. & $\%$ & n. & $\%$ \\
\cline { 2 - 7 } & $\mathrm{n}$. & 44 & 13 & 21 & 151 & 50 \\
\hline $\begin{array}{l}\text { Municipal } \\
\text { development }\end{array}$ & 164 & & & & & \\
\hline Master plan & 48 & 13 & 4 & 7 & 44 & 15 \\
\hline Emergency & 45 & 12 & 10 & 13 & 35 & 12 \\
\hline Risk reduction & 29 & 8 & 2 & 3 & 27 & 9 \\
\hline Sustainable & 25 & 7 & 6 & 5 & 19 & 6 \\
\hline Mitigation & 23 & 6 & 13 & 17 & 10 & 3 \\
\hline Adaptation & 11 & 3 & 7 & 9 & 4 & 1 \\
\hline Smart city & 15 & 4 & 10 & 13 & 5 & 2 \\
\hline Resilience & 6 & 2 & 4 & 5 & 2 & 1 \\
\hline Other & 10 & 3 & 5 & 7 & 5 & 2 \\
\hline Total & 376 & 100 & 74 & 100 & 302 & 100 \\
\hline
\end{tabular}

USA, are long term tools that define policies for the next 20 years. A diagnosis (participated) of the shortcomings precedes planning of measures. The most accurate plans spread measures over time, defining the cost and the sources of funding, the body responsible and the system of monitoring and evaluation. The MDP was born to promote local development, not to respond to $\mathrm{CC}$, so it does not characterize the local climate, unless obliged by law to do so (Niger). However, different measures fall between those that are typical for mitigation (tree planting, pedestrian and cycle mobility, waste reducing/reusing/recycling) or adaptation (storm water drainage, resettlement from hazard prone areas). In the Tropics, MDPs are the first tools to contain measures for adaptation to CC: Djougou and Malanville, Benin (2003 and 2004), La Ceiba, Honduras (2005), Estelí, Nicaragua (2005), Thane (2005) and Mysore (2006), India. MDPs with climate measures have been generalized in Colombia, India, Mexico and other tropical countries since 2012. Odessa and Laredo are the first medium-sized cities to adopt a comprehensive plan (1988 and 1991). Glendele and Honolulu are the first to have a general plan (2002).

\section{Master Plans}

Master plans (13\%) are the second most widespread tools. They first started to be implement in big cities (Belo Horizonte 1996, Kigali 2004, São Luís 2005) and then in medium-sized cities (Petrolina, São João Meriti, Uberlandia 2006). These plans are medium-long term and don't just define land use, but also transportation, water and sanitation, waste, economic and social development (education, health, access to housing, tourism) and environment, without, however, specifying the costs of the measures or their distribution over time, and without foreseeing the impacts or a device for monitoring and reporting $(M \& R)$.

\section{Emergency Plans}

This group (12\%) is especially common in South America but not in tropical Africa. $61 \%$ of plans traced have been drawn up over the past three years. 
There are two types of plan: those that specify the arrangements a local government must make to become operative in the event of a disaster (La Esperanza, Sincelejo), and those that are operational (Santiago de Cali), describing the sequence of established operations that the various actors are called upon to implement in order to respond to the emergency. These plans are, at times, limited to one hazard only (heat in Ahmedabad, drought in Campinas, floods in Machala). Though they do not solely refer to CC-related disasters, they overlap mitigation/adaptation plans in relation to the definition of zones that are either exposed or at risk. In cities that have both an emergency plan and an adaptation plan, the two tools refer to different bodies, specifically civil defence or fire brigade in the first case, city council/environmental sector in the second.

The plan is implemented after an early warning. The warning should be strategically communicated to areas that are exposed to the hazard, especially in the event of floods. This only occurs in 30\% of cases. However, only $18 \%$ of plans define the early warning threshold. Barely $20 \%$ define hazard prone areas and only in half the cases do they make use of maps. Emergency or contingency plans "analyse specific potential events or emerging situations that might threaten society or the environment, and establish arrangements in advance to enable timely, effective and appropriate responses to such events and situations" (UNISDR 2009: 7). Once again, a national law envisages the disaster prevention device (Colombia, India, Philippines, etc.) or civil defence (Brazil), and subsequently the creation of municipal emergency committees to draw up dedicated plans. In other cases (Texas), the contingency plan is drawn up in compliance with rules defined by state commissions. The first medium-sized cities to implement an emergency plan were El Progreso, Honduras (1998), Granada, Nicaragua (2005), San Andres de Tumaco, Colombia (2006) and Tacna, Peru (2007), followed by two big cities: Tegucigalpa, Honduras (2007) and Hyderabad, Pakistan (2008).

\section{Risk Reduction Plans}

These scarcely used plans (8\%), contain structural and non-structural measures described in detail (costs and methods of financing), which respond to the hazards to which the city is exposed. Sometimes these plans lack climate characterization. Risk reduction plans are in place in Brazil, Cameroun, Colombia, Nicaragua and Philippines. One of the first medium-sized cities to adopt these plans is Granada, Nicaragua (2005), followed, among the big cities, by Maçeio and Vitoria, Brazil (2007).

\section{Mitigation Plans}

This group collects $6 \%$ of the planning tools traced. These plans focus on the need "to reduce the sources or enhance the sinks of greenhouse gases" (IPCC 2014: 19). Mitigation plans comprise the emission inventory, GHG reduction goals and measures. The most detailed plans estimate the expected reduction of emissions, the risks resulting from $\mathrm{CC}$, the cost, funding sources and the timing of every measure. The capability assessment, which considers the technical and political ability to implement the measures, is rarely carried out. The first mitigation plans for big tropical cities were prepared for Bangkok, Thailand (2007) and Miami, USA 
(2008), and authentic climate plans, with numerous measures, for medium-sized cities are those of Cairns and Darwin, Australia (2009 and 2010).

\section{Sustainable Action Plans}

These plans $(6 \%)$ were introduced by the Inter-American Development Bank starting in 2012. They contain mitigation measures (tree planting, pedestrian and cycle mobility) and adaptation measures (early warning and stormwater drainage) effective in the midterm. Their greatest limit is that they are stand-alone plans, not envisaged by law, which the cities are not required to set up.

\section{Smart City Proposals}

Smart city proposals are the ultimate planning tool. Employed in India (in about twenty cities) and in Indonesia (Bogor 2015), these tools are still little used in the Tropics (4\%). They are based on broad consultation and, in general, concern one or just a few parts of the city. The accent is on technological innovation (for example, sensors which tell you when trash bins are full, etc.) more than tackling big urban problems (slum upgrading and informal settlement regularization, poverty and risk reduction). However, they also contain measures for mitigation (reduction of vehicle traffic) and adaptation (storm water drainage), which are not deriving from climate characterization or from risk assessment.

\section{Adaptation Plans}

Adaptation planning focuses on "the adjustment in natural or human systems in response to actual or expected climatic stimuli or their effects, which moderates harm or exploits beneficial opportunities" (UNISDR 2009). Plans include non-structural measures (e.g. early warning, flood drills) and structural measures (flood barriers, stormwater drainage, and resettlement of inhabitants from flood-prone areas). In the latter case, if local adaptation plans are not expressly envisaged by the general environment protection law or by a specific national law (Philippines 2007), they are implicit in the Local Government Act of various countries (Australia 1999) when council functions are specified and often extended to "protect its area from natural hazards and to mitigate the effects of such hazards." In other cases, the individual cities implement the specific national commitments made at the United Nations Framework Convention for Climate Change (UNFCCC). Adaptation planning is funded by dedicated programmes, but is still scarcely practised (3\%) as it has not been able to be implemented on the same global mobilisation levels as GHG mitigation. The first examples of adaptation plans are those of Darwin (2010) for medium-sized cities and of Semarang (2010) for big cities.

\section{Resilience Strategies}

Resilience strategies (2\%) are common in Asia only. The target of these strategies is to strengthen planning, organisational and management skills in view of a disaster, rather than implementing structural measures. Aside from structural measures, they define many actions based on the accumulation of information (databases on hazards, hazard prone area identification), management (establishing a CC coordination office), training and awareness. The most accurate resilience strategies identify 
vulnerabilities, list the actions required to reduce them, define implementation phases and the relevant financial mechanism. Since 2010, UNISDR has supported local resilience strategies, especially partnered in Asia by the Rockefeller foundation. Can Tho (Viet Nam) was one of the first big cities to implement a Resilience plan (2010), with Sorsogon (Philippines) being one of the first medium-sized cities to do so (2010).

\subsubsection{Quality of Climate Planning}

Several parameters, such as internal consistency between objectives, priorities and measures (Baer 1997; Norton 2008; Baker et al. 2012), or between climate characterization and measures, can be considered to assess the quality of plans. In our case, we are interested in assessing whether the currently formulated plans are able to guide the implementation of measures that reduce the impact of $\mathrm{CC}$, and whether the measures they propose are really appropriate to reduce GHG emissions and impacts of $\mathrm{CC}$. The focus will then be on 10 indicators: climate characterization, number, quantification, relevance, expected impact, cost, funding sources, timetable and responsibility for each measure, monitoring plan implementation and reporting, brought together in the QCPI, which can theoretically reach the maximum value of 10 .

Tropical cities have a QCPI of 2.5. Such a low score is due to the fact that just $2 \%$ of the plans specify the impact that the measures are expected to have, $6 \%$ characterize local climate, $18 \%$ quantify each measure, $20 \%$ of the plans indicate the cost of the measures and include a timetable for implementation, $22 \%$ have more than 10 climate measures and $24 \%$ specify the source of funding (Table 10.7).

Table 10.7 Frequency of indicators used in the QCPI according to tropical city size

\begin{tabular}{l|l|l|l|l|l|l}
\hline \multirow{2}{*}{ Indicator } & \multicolumn{9}{l}{ Climate plans according city' size } \\
\cline { 2 - 8 } & \multicolumn{2}{l}{ Big } & \multicolumn{2}{l}{ Medium } & \multicolumn{2}{l}{$\begin{array}{l}\text { Big and } \\
\text { medium-sized }\end{array}$} \\
\cline { 2 - 9 } & $\#$ & $\%$ & $\#$ & $\%$ & $\#$ & $\%$ \\
\hline 1. Climate characterization & 9 & 14 & 11 & 4 & 20 & 6 \\
\hline 2. Number of measures & 24 & 36 & 42 & 19 & 76 & 22 \\
\hline 3. Quantification of measures & 11 & 17 & 50 & 18 & 61 & 18 \\
\hline 4. Relevance of measures & 49 & 74 & 109 & 39 & 158 & 46 \\
\hline 5. Potential impact & 3 & 5 & 4 & 1 & 7 & 2 \\
\hline 6. Measure cost & 25 & 38 & 118 & 42 & 143 & 42 \\
\hline 7. Measure funds & 15 & 23 & 69 & 25 & 84 & 24 \\
\hline 8. Measure responsible & 14 & 21 & 56 & 30 & 70 & 20 \\
\hline 9. Monitoring and reporting & 5 & 8 & 86 & 31 & 91 & 26 \\
\hline 10. Time table & 17 & 26 & 122 & 44 & 70 & 20 \\
\hline Plan considered \# & 66 & 100 & 280 & 100 & 346 & 100 \\
\hline
\end{tabular}


Table 10.8 QCPI in tropical cities according to city size and plan category

\begin{tabular}{l|l|l|l}
\hline \multirow{2}{*}{ Climate plan categories } & \multicolumn{2}{|l}{ City size } & \multicolumn{2}{l}{} \\
\cline { 2 - 4 } & Big QCPI & Medium QCPI & Big and medium QCPI \\
\hline Resilience & 4.8 & 3.3 & 4.0 \\
\hline Sustainable action & 1.0 & 3.7 & 3.4 \\
\hline Mitigation & 3.2 & 4.0 & 3.5 \\
\hline Sustainable action & 1.0 & 3.7 & 3.4 \\
\hline Adaptation & 2.8 & 5.0 & 3.1 \\
\hline Smart city & 2.7 & 3.2 & 2.9 \\
\hline General & - & 2.9 & 2.9 \\
\hline Municipal development & 2.9 & 2.7 & 2.7 \\
\hline Risk reduction & 1.0 & 1.8 & 1.8 \\
\hline Comprehensive & - & 1.6 & 1.6 \\
\hline Master & 1.1 & 1.0 & 1.0 \\
\hline All & 2.7 & 2.2 & 2.5
\end{tabular}

However, the QCPI varies depending on the size of the cities. Big cities have higher quality plans (QCPI 2.7) than those of medium-sized cities (QCPI 2.2) (Table 10.8). This is due to the greater frequency in the former of resilience strategies, mitigation, adaptation plans, tools which present the highest QCPI (4.8, 3.2 and 2.8 and 2.7 respectively). Medium-sized cities on the other hand are characterized by municipal developments and master plans, which have a low QCPI (2.7 and 1.0). Although the average QCPI values are fairly low, certain categories of plans have some high quality tools such as Cairns' mitigation plan (QCPI = 8), the MDPs of Concepcion de la Vega and Tanout, the resilience plan of Semarang, the risk reduction plans of Palmira and Puerto Plata (QCPI $=7$ ).

In short, stand-alone plans (resilience, mitigation, sustainable action, adaptation, smart city) have higher QCPI than the general plans (municipal development, general, comprehensive, master plans), regardless of the size of the city.

The relevance indicator can, however, be misleading. When climate planning is carried out, not all cities start from the same baseline. For example, separate glass, metal, paper and food waste and recycling programs or the use of LED bulbs for street lighting can be innovative measures in one city, while they are so consolidated in another that they need not even be mentioned among the measures established by the plan. Hence, the absence of certain measures does not always indicate lack of detail or visionary planning.

The 346 climate plans of tropical cities traced (the remaining are emergency plans with no measures and other plans with little detailed measures), concern the main jurisdiction only, with the sole exception of Miami, where the whole metropolitan area was considered. Planning on a metropolitan scale stems from the need to harmonise the measures of many jurisdictions and authorities (water, etc.), whose consent is required (Revi et al. 2014: 44).

Plans for metropolitan areas include building awareness, studies and assessments to ensure that mitigation/adaptation measures become rooted in each jurisdiction, 
Table 10.9 Aim of measures in 271 climate plans for tropical cities

\begin{tabular}{l|l|l}
\hline \multirow{2}{*}{ Measure goal } & \multicolumn{2}{|l}{$\begin{array}{l}\text { Measures for Big and medium } \\
\text { sized tropical cities }\end{array}$} \\
\cline { 2 - 3 } & $\mathrm{N}^{\circ}$ & $\%$ \\
\hline Adaptation & 96 & 62 \\
\hline Mitigation & 47 & 31 \\
\hline Adaptation \& mitigation & 11 & 7 \\
\hline All & 154 & 100 \\
\hline
\end{tabular}

Table 10.10 Structural and non-structural measures in 271 climate plans for tropical cities

\begin{tabular}{l|l|l|l|l|l|l}
\hline Measure nature & \multicolumn{2}{l|l}{$\begin{array}{l}\text { Big and } \\
\text { medium-sized } \\
\text { cities }\end{array}$} & \multicolumn{2}{l|}{ Big cities } & \multicolumn{2}{l}{$\begin{array}{l}\text { Medium-sized } \\
\text { cities }\end{array}$} \\
\cline { 2 - 8 } & $\mathrm{N}^{\circ}$ & $\%$ & $\mathrm{~N}^{\circ}$ & $\%$ & $\mathrm{~N}^{\circ}$ & $\%$ \\
\hline Structural & 886 & 61 & 245 & 66 & 650 & 61 \\
\hline Non-structural & 256 & 39 & 125 & 34 & 420 & 39 \\
\hline Total & 1142 & 100 & 370 & 100 & 1070 & 100 \\
\hline
\end{tabular}

and fundraising initiatives. Municipal plans focus instead on direct impact, especially on municipal facilities (offices, transportation, employees), and on sectors in which the Municipality has regulatory authority (private construction works, road systems, waste, education, etc.).

\subsubsection{Climate Measures}

As regards measures, there are two aspects of interest: knowing the main aims of the measures (mitigation or adaptation) and checking their nature (structural or non-structural). The survey of 346 climatic plans ascertained that adaptation prevails $(62 \%)$ over mitigation (Table 10.9).

Secondly, structural measures (e.g.: tree planting, storm water drainage, cycle lanes, resettlement) prevail (61\%) over those of a non-structural nature (e.g.: early warning system, emergency plan, risk maps, air quality monitoring, etc.) (39\%) and this prevalence is valid for both big and medium-sized cities (Table 10.10).

\subsection{Discussion}

The survey on climate plans in the Tropics has allowed in-depth understanding of the intentions of cities to tackle climate change. Its results belie all previous knowledge. Firstly, climate planning in the Tropics has risen considerably in the past seven years, and now concerns a fourth of all cities. 
The option between stand-alone and existing plans (UN-Habitat 2015) is soon unravelled. Three quarters of climate-action is carried out using existing tools: MDPs and master plans, especially in medium-sized cities. Stand-alone plans are used only by big cities. The mainstreaming of climate measures in the existing tools has several advantages in theory (UN-Habitat 2015; Revi et al. 2014; Basset and Shandas 2010): decrease of hazard exposure (prohibition of building on hazard prone areas), increased chances of implementation (MDP), mitigation burden shared with private sector (mitigation imposed upon developers), cost reduction (measures already funded in other sectors), reduced contribution to CC (regulations on building materials). In practice, we have found that mainstreaming presents several limitations compared to stand-alone plans. Specifically, in the case of municipal development plans, we notice very few climatic measures (an average of 4). In the case of master plans other limitations include lack of characterisation of the hazard, prevalence of measures that only concern land use (setback to be complied with during construction works, and land use allowed), lack of priority and scheduling, no reference to the potential impact of works, rare monitoring and reporting of the plan implementation.

Secondly, previous knowledge of climate measures is belied. In the Tropics, the focus isn't on flood (Hunt and Watkiss 2011). It is on air quality (47 measures), drought, heat, fire, landslide and wind (28 measures), with flood coming last (16 measures). The equivalent measures aren't related to mitigation (Buckley 2010; Anguelowsky and Carmin 2011) but to adaptation. Lastly, contrary to the claims made by Wamsler et al. (2013), the measures are not always the same in the different contexts with a prevalence of non-structural measures. They depend on the economy to which the city belongs (OECD, BRICS, DC, LDCs) and on the size of the city, and are mainly structural.

Thirdly, the QCPI confirms the observations of Wheeler (2008), Tang et al. (2010) and Preston et al. (2011) on smaller contexts: plan-quality is still low. Climate plans are not particularly action driven and their measures are inadequate to significantly reduce GHG emissions and the impacts of CC.

The existing plans, in which to carry out the mainstreaming of climate measures, present the lowest quality, regardless of the size of the city and the economy to which it belongs. Mainstreaming requires a considerable amount of work to raise the quality of MDPs, MPs and RMPs.

Our survey has two main limits. The first is that it considers no plans other than those accessible in Chinese, English, French, Spanish and Portuguese. Secondly, 
the QCPI can be misleading in relation to the relevance of measures: the absence of measures in some sectors (LED, drainage) can mean that the city in question is already sufficiently well-equipped.

\subsection{Conclusion}

This chapter aimed to characterize climate planning (dissemination and trend) and to ascertain its quality in a homogeneous context: the big and medium-sized cities of the Tropics. The survey of 338 tropical cities (Table 10.11) identified two important trends. First, strong growth of climate plans, especially in big cities. Second, dissemination of climatic measures mainly in MDPs.

The assessment of the quality of plans using the QCPI made it possible to identify the weaknesses that could be eliminated in the second-generation plans.

Local climate characterization (temperature, precipitations, sea level rise) is absent in all classes of city, as are indications on its future trend: it is paradoxical that $84 \%$ of plans define climate measures without knowing the local impacts of the climate and the trends expected for the next 20 years.

The potential impacts of the measures are estimated by just $2 \%$ of plans.

A measure which could significantly reduce emissions and impacts is present in just $46 \%$ of plans. For example, in relation to buildings, we have found that measures rarely make the construction of carbon-neutral structures compulsory.

Only $26 \%$ of climate plans describe the monitoring and reporting system and $22 \%$ of plans for medium-sized cities envisage more than 10 climate measures.

These considerations should sound as a recommendation for the multi-bilateral bodies that finance local climate plans, for the NGOs that accompany their formation, for the local governments that approve them and for the central governments that draw up the guidelines for their preparation.

This survey can be furthered in three ways: (i) passing from the occasional survey to tracking, (ii) checking whether the second-generation plans have overcome the weaknesses highlighted by the ten indicators of the QCPI, (iii) passing from the survey on the plan quality to that on plan implementation. Sometimes, the absence of details in planning is a choice made by local governments, to ensure long life to the plans for instance. 
Table 10.11 Big and medium-sized cities of the Tropics provided with A-Adaptation, CD-City Development, C-Comprehensive, Ci-City, DM-Disaster management, E-Emergency, G-General, ID-Integrated development, M-Mitigation, MI-Municipal Investment, M-Master, R-Resilience, RR-Risk reduction, SAP-Sustainable Action, S-Strategic, SC-Smart city plans

\begin{tabular}{|c|c|c|c|c|}
\hline City & \begin{tabular}{|l|} 
Country ISO \\
$3166-1$ \\
\end{tabular} & $\begin{array}{l}\text { Population } \\
\text { million }\end{array}$ & Plan type & Year \\
\hline \multicolumn{5}{|l|}{ Big } \\
\hline Agra & IND & 1.6 & MDP & 2006 \\
\hline Ahmedabad & IND & 6.3 & E, SC & 2015,16 \\
\hline Aurangabad & IND & 1.1 & MDP & 2012 \\
\hline Bangalore & IND & 8.4 & MDP, O & 2011,2015 \\
\hline Bangkok & THA & 8.2 & $\mathrm{M}$ & 2007 \\
\hline Barranquilla & $\mathrm{COL}$ & 1.2 & A & 2012 \\
\hline Belem & BRA & 1.4 & MP & 2008 \\
\hline Belo Horizonte & BRA & 2.5 & MP, M & 1996,2013 \\
\hline Bhopal & IND & 2.8 & MDP & 2006 \\
\hline Bogor & IDN & 1.0 & $\mathrm{SC}$ & 2015 \\
\hline Brasilia & BRA & 2.6 & MP & 2009 \\
\hline Bucaramanga & $\mathrm{COL}$ & 1.0 & MDP & 2016 \\
\hline Can Tho & VNM & 1.2 & $\mathrm{R}$ & 2010 \\
\hline Cartagena das Indias & COL & 1.0 & A, MDP & 2012,13 \\
\hline Cebu City & PHL & 2.5 & $\mathrm{M}$ & 2013 \\
\hline Chennai & IND & 4.2 & SC & 2015 \\
\hline Coimbatore & IND & 1.6 & MDP & 2002 \\
\hline Dakar & SEN & 2.5 & MP & 2010 \\
\hline Delhi & IND & 16.8 & E, SC & 2015 \\
\hline Dubai & UAE & 1.8 & M & 2014 \\
\hline Fortaleza & BRA & 2.6 & MP, M & 2009,2012 \\
\hline Goiania & BRA & 1.3 & SAP, RR & 2012 \\
\hline Guayaquil & ECU & 2.3 & A & 2012 \\
\hline Haikou & $\mathrm{CHN}$ & 2.2 & E, M & 2014,2015 \\
\hline Ho Chi Minh City & VNM & 8.2 & $\mathrm{R}$ & 2013 \\
\hline Hyderabad & IND & 6.8 & $\mathrm{E}$ & 2013 \\
\hline Hyderabad & PAK & 1.1 & $\mathrm{E}$ & 2003 \\
\hline Indore & IND & 2.0 & $\mathrm{R}$ & 2015 \\
\hline Jabalapur & IND & 1.1 & $\mathrm{SC}$ & 2015 \\
\hline Jaipur & IND & 3.3 & $\mathrm{SC}$ & 2012 \\
\hline Kampala & UGA & 1.7 & Other & 2014 \\
\hline Kaoshiung & TWN & 3.0 & $\mathrm{M}$ & 2011,2014 \\
\hline Karachi & PAK & 23.0 & $\mathrm{~A}$ & 2013 \\
\hline Kigali & RWA & 1.1 & MP & 2004 \\
\hline Lagos & NGA & 9.0 & A & 2013 \\
\hline Lima & PER & 8.5 & $\mathrm{E}$ & 2011 \\
\hline
\end{tabular}


Table 10.11 (continued)

\begin{tabular}{|c|c|c|c|c|}
\hline City & $\begin{array}{l}\text { Country ISO } \\
3166-1\end{array}$ & $\begin{array}{l}\text { Population } \\
\text { million }\end{array}$ & Plan type & Year \\
\hline Ludhiana & IND & 1.4 & SC & 2015 \\
\hline Maçeio & BRA & 1.0 & RR & 2007 \\
\hline Managua & NIC & 1.3 & MDP & 2013 \\
\hline Manaus & BRA & 2.0 & MP & 2014 \\
\hline Maracaibo & VEN & 2.0 & MDP & 2005 \\
\hline Miami & USA & 2.6 & M & 2008 \\
\hline Mombasa & TZA & 1.1 & MDP & 2013 \\
\hline Montería & $\mathrm{COL}$ & 1.0 & M & 2011 \\
\hline Nagpur & IND & 2 & & \\
\hline Phoenix City & USA & 1.5 & M & 2009 \\
\hline Pimpri Chinchwad & IND & 1.7 & MDP & 2006 \\
\hline Puducherry & IND & 1.2 & MDP & 2013 \\
\hline Pune & IND & 5.1 & SC & 2015 \\
\hline Raipur & IND & 1.4 & MDP & 2014 \\
\hline Recife & BRA & 1.6 & $\begin{array}{l}\text { MDP, } \\
\text { SAP }\end{array}$ & 2008, 2014 \\
\hline Rio de Janeiro & BRA & 6.5 & MP, M & 2011, 2014 \\
\hline Salvador de Bahia & BRA & 2.9 & E, MP & 2015,2016 \\
\hline San Juan Lurigancho & PER & 1.1 & MDP & 2011 \\
\hline Santa Cruz de la Sierra & BOL & 2.5 & MDP & 2016 \\
\hline Santiago de Cali & $\mathrm{COL}$ & 2.1 & $\mathrm{E}$ & 2009 \\
\hline São Luís & BRA & 1.0 & MP & 2006 \\
\hline Semarang & IDN & 1.6 & $\mathrm{R}$ & 2010 \\
\hline Singapore & SGP & 3.8 & $\mathrm{M}$ & 2012 \\
\hline Surat & IND & 4.8 & $\mathrm{R}$ & 2011 \\
\hline Tainan & $\mathrm{CHN}$ & 1.9 & A, E & 2010 \\
\hline Tegucigalpa & HND & 1.2 & $\mathrm{E}$ & 2007 \\
\hline Thane & IND & 1.3 & MDP & 2005 \\
\hline Vasai Virar & IND & 1.2 & MDP & 2009 \\
\hline Visakapatnam & IND & 2.0 & SC & 2016 \\
\hline \multicolumn{5}{|l|}{ Medium-sized } \\
\hline Abomey Calavi & BEN & 0.7 & MDP & 2005 \\
\hline Acapulco & MEX & 0.7 & MDP & 2012 \\
\hline Acuña & MEX & 0.2 & MDP & 2014 \\
\hline Aganang & ZAF & 0.1 & ID, DM & 2009,2012 \\
\hline Agartala & IND & 0.4 & DP & 2011 \\
\hline $\begin{array}{l}\text { Agglomération centrale } \\
\text { Martinique }\end{array}$ & MTQ & 0.2 & $\mathrm{M}$ & 2012 \\
\hline Altamira & MEX & 0.2 & MDP & 2011 \\
\hline Ananindeua & BRA & 0.5 & MP & 2006 \\
\hline
\end{tabular}


Table 10.11 (continued)

\begin{tabular}{|c|c|c|c|c|}
\hline City & $\begin{array}{l}\text { Country ISO } \\
3166-1\end{array}$ & $\begin{array}{l}\text { Population } \\
\text { million }\end{array}$ & Plan type & Year \\
\hline Anapolis & BRA & 0.4 & MP & 2016 \\
\hline Apartado & $\mathrm{COL}$ & 0.2 & MDP & 2012 \\
\hline Aracaju & BRA & 0.6 & MP & 2010 \\
\hline Armenia & $\mathrm{COL}$ & 0.3 & MP & 2009 \\
\hline Asansol & IND & 0.6 & MDP & 2006 \\
\hline Babahoyo & ECU & 0.1 & E & 2009 \\
\hline Bacolod & PHL & 0.5 & A & 2013 \\
\hline Ba-Phalaborwa & ZAF & 0.2 & DM, IDP & 2012,2015 \\
\hline Barrancabermeja & $\mathrm{COL}$ & 0.3 & MDP & 2012 \\
\hline Belagavi & IND & 0.5 & SC & 2016 \\
\hline Bello & $\mathrm{COL}$ & 0.4 & MDP & 2012 \\
\hline Berhampur & IND & 0.4 & CDP & 2011 \\
\hline Betim & BRA & 0.4 & MP & 2007 \\
\hline Blouberg & ZAF & 0.2 & MDP & 2015 \\
\hline Boa Vista (Roirama) & BRA & 0.3 & MP & 2006 \\
\hline Bohicon & BEN & 0.1 & MDP & 2008 \\
\hline Buenaventura & $\mathrm{COL}$ & 0.4 & MP & 2001 \\
\hline Cairns & AUS & 0.2 & M & 2010 \\
\hline Campeche & MEX & 0.9 & SAP & 2015 \\
\hline Campina Grande & BRA & 0.4 & MP & 2006 \\
\hline Campo Goyatacazes & BRA & 0.5 & MP & 2007 \\
\hline Campos & BRA & 0.5 & MP & 2007 \\
\hline Cancun & MEX & 0.7 & MDP & 2014 \\
\hline Cariacica & BRA & 0.4 & MP & 2007 \\
\hline Carmen & MEX & 0.1 & MDP & 2012 \\
\hline Carrefour & HTI & 0.5 & MIP & 2011 \\
\hline Cartago & $\mathrm{COL}$ & 0.2 & MP & 2000 \\
\hline Chandler, AZ & USA & 0.3 & E, GP & 2006,2008 \\
\hline $\begin{array}{l}\text { Chetumal see } \\
\text { Othon P. Blanco }\end{array}$ & MEX & 0.2 & MDP & 2013 \\
\hline Chiclayo & PER & 0.5 & MDP & 2015 \\
\hline Chilón & MEX & 0.1 & MDP & 2012 \\
\hline Choloma & HND & 0.2 & MDP & 2003 \\
\hline Cienaga & $\mathrm{COL}$ & 0,1 & MDP & 2012 \\
\hline Ciudad Madero & MEX & 0.2 & MDP & 2013 \\
\hline Ciudad Valles & MEX & 0.2 & MDP & 2004 \\
\hline Concepción de la Vega & DOM & 0.2 & MDP & 2016 \\
\hline Contagem & BRA & 0.6 & RR & 2007 \\
\hline Coral Springs & USA & 0.2 & $\mathrm{CP}$ & 2008 \\
\hline
\end{tabular}


Table 10.11 (continued)

\begin{tabular}{|c|c|c|c|c|}
\hline City & $\begin{array}{l}\text { Country ISO } \\
3166-1\end{array}$ & $\begin{array}{l}\text { Population } \\
\text { million }\end{array}$ & Plan type & Year \\
\hline Cordoba & MEX & 0.1 & MDP & 2014 \\
\hline Cotonou & BEN & 0.8 & MDP & 2008 \\
\hline Cuiabá & BRA & 0.6 & MP & 2008 \\
\hline Cumana & VEN & 0.8 & PAS & 2015 \\
\hline Dargol & NER & 0.1 & MDP & 2013 \\
\hline Darwin & AUS & 0.1 & $\mathrm{M}, \mathrm{S}$ & 2011,2012 \\
\hline Davanagere & IND & 0.4 & SC & 2016 \\
\hline Ding'an & $\mathrm{CHN}$ & 0.3 & $\mathrm{M}$ & 2016 \\
\hline Dioundiou & NER & 0.1 & MDP & 2009 \\
\hline Ditsobotla & ZAF & 0.2 & IDP & 2015 \\
\hline Djougou & BEN & 0.3 & MDP & 2003 \\
\hline Dongfang & $\mathrm{CHN}$ & 0.4 & E & 2015 \\
\hline Dori & BFA & 0.1 & MDP & 2008 \\
\hline Dos Quebradas & $\mathrm{COL}$ & 0.2 & $E$ & 2011 \\
\hline Duque de Caxias & BRA & 0.9 & RR & - \\
\hline El Porvenir & PER & 0.1 & MDP & 2014 \\
\hline El Progreso & HND & 0.2 & $E$ & 1998 \\
\hline Envigado & $\mathrm{COL}$ & 0.2 & MP & 2011 \\
\hline Ephraim Mogale & ZAF & 0.1 & IDP & 2015 \\
\hline Esmeraldas & ECU & 0.5 & E & 2012 \\
\hline Estelí & NIC & 0.1 & MDP, A & 2005,12 \\
\hline Feira de Santana & BRA & 0.6 & MP & 2013 \\
\hline Florencia & $\mathrm{COL}$ & 0.2 & $\mathrm{E}$ & 2013 \\
\hline Floridablanca & $\mathrm{COL}$ & 0.2 & MDP & 2012 \\
\hline Fort Lauerdale & USA & 0.2 & E, CP & 2008,2015 \\
\hline Frances Baard & ZAF & 0.4 & DM, IDP & 2006,2015 \\
\hline Fusagasugà & $\mathrm{COL}$ & 0.1 & MP & 2001 \\
\hline Gilbert & USA & 0.2 & GP & 2012 \\
\hline Glazoué & BEN & 0.1 & MDP & 2014 \\
\hline Glendale, AZ & USA & 0.2 & GP & 2002 \\
\hline Gomez Palacio & MEX & 0.3 & MDP & 2010 \\
\hline Granada & NIC & 0.1 & $\mathrm{E}$ & 2005,09 \\
\hline General Escobedo & MEX & 0.4 & MDP & 2010 \\
\hline Greater Giyani & ZAF & 0.2 & IDP, DM & 2012,2013 \\
\hline Greater Letaba & ZAF & 0.2 & E, IDP & 2012,2015 \\
\hline Greater Tubatse & ZAF & 0.3 & MDP & 2016 \\
\hline Greater Tzaneen & ZAF & 0.4 & $\begin{array}{l}\text { DMP, } \\
\text { IDP }\end{array}$ & 2012,2013 \\
\hline Guadalajara de Buga & $\mathrm{COL}$ & 0.1 & MP & 2000 \\
\hline
\end{tabular}


Table 10.11 (continued)

\begin{tabular}{|c|c|c|c|c|}
\hline City & $\begin{array}{l}\text { Country ISO } \\
3166-1\end{array}$ & $\begin{array}{l}\text { Population } \\
\text { million }\end{array}$ & Plan type & Year \\
\hline Guadalupe & MEX & 0.7 & $\begin{array}{l}\text { MDP, } \\
\text { MP }\end{array}$ & 2005,2016 \\
\hline Guntur & IND & 0.5 & CDP & 2006 \\
\hline Guwahati & IND & 0.8 & $\mathrm{SC}$ & 2016 \\
\hline Hat Yai & THA & 0.2 & A & 2016 \\
\hline Heredia & CRI & 0.1 & MDP & 2014 \\
\hline Hermosillo & MEX & 0.8 & MP & 2015 \\
\hline Hialeah & USA & 0.2 & $\mathrm{CP}$ & 2007 \\
\hline Honolulu & USA & 0.3 & GP, E, M & $\begin{array}{l}2002,2008 \\
2014\end{array}$ \\
\hline Hoshanghad & IND & 0.1 & MDP & 2011 \\
\hline Hué & VNM & 0.3 & A & 2014 \\
\hline Ibagué & $\mathrm{COL}$ & 0.5 & E, MDP & 2011,2016 \\
\hline Iguala & MEX & 0.1 & MDP & 2015 \\
\hline Iloilo city & PHL & 0.4 & A & 2014 \\
\hline Indipendencia & PER & 0.2 & MDP & 2011 \\
\hline Iquitos & PER & 0.4 & MP & 2011 \\
\hline Itagui & $\mathrm{COL}$ & 0.2 & E, MDP & 2012,2016 \\
\hline Jaboatão de Guararapes & BRA & 0.7 & MP & 2008 \\
\hline Jamshedpur & IND & 0.7 & MDP & 2006 \\
\hline Jean Rabel & HTI & 0.1 & MDP & 2013 \\
\hline Jiutepec & MEX & 0.2 & MDP & 2016 \\
\hline João Pessoa & BRA & 0.8 & MP, SAP & $2008,-$ \\
\hline Jozini & $\mathrm{ZAF}$ & 0.2 & IDP & 2013 \\
\hline Kagisano-Molopo & ZAF & 0.1 & IDP & 2005 \\
\hline Kakinada & IND & 0.3 & MP & 2016 \\
\hline Kalfou & NER & 0.1 & MDP & 2014 \\
\hline Klouékanmè & $\mathrm{BEN}$ & 0.1 & MDP & 2010 \\
\hline Kochi & IND & 0.6 & $\mathrm{SC}$ & 2016 \\
\hline Kollam & IND & 0.4 & CDP & 2014 \\
\hline La Ceiba & HND & 0.2 & MDP & 2005 \\
\hline La Esperanza & PER & 0.1 & $\mathrm{E}$ & 2015 \\
\hline $\mathrm{La} \mathrm{Paz}$ & MEX & 0.2 & M & 2012 \\
\hline Lepelle-Nkumpi & ZAF & 0.2 & IDP & 2016 \\
\hline Lephalale & $\mathrm{ZAF}$ & 0.1 & $\begin{array}{l}\text { DMP, } \\
\text { IDP }\end{array}$ & 2012,2015 \\
\hline Limassol & CYP & 0.1 & $\mathrm{M}$ & 2013 \\
\hline Los Mochis & MEX & 0.3 & MP & 2014 \\
\hline Machala & ECU & 0.2 & $\mathrm{E}$ & 2009 \\
\hline Magangué & $\mathrm{COL}$ & 0.2 & MDP & 2012 \\
\hline
\end{tabular}


Table 10.11 (continued)

\begin{tabular}{|c|c|c|c|c|}
\hline City & $\begin{array}{l}\text { Country ISO } \\
3166-1\end{array}$ & $\begin{array}{l}\text { Population } \\
\text { million }\end{array}$ & Plan type & Year \\
\hline Makhado & ZAR & 0.5 & IDP, RR & 2012,2014 \\
\hline Makhuduthamaga & ZAR & 0.3 & $\begin{array}{l}\text { IDP, } \\
\text { DMP }\end{array}$ & 2010,2013 \\
\hline Malambo & $\mathrm{COL}$ & 0.1 & MDP & 2012 \\
\hline Malanville & BEN & 0.1 & MDP & 2004 \\
\hline Managua districts & NIC & 0.3 & MP & 2013 \\
\hline Manzanillo & MEX & 0.2 & MDP & 2015 \\
\hline Matamoros & MEX & 0.5 & MP & 2005 \\
\hline Matola & $\mathrm{MOZ}$ & 0.9 & $\mathrm{E}$ & 2015 \\
\hline Mazatlan & MEX & 0.4 & MDP & 2014 \\
\hline Merida & MEX & 0.8 & MDP & 2015 \\
\hline Mesa & USA & 0.4 & E, GP & 2009,2014 \\
\hline Mexicali & MEX & 0.7 & MDP & 2014 \\
\hline Miami City & USA & 0.4 & $\mathrm{CP}$ & 2015 \\
\hline Miami Gardens & USA & 0.1 & $\mathrm{CP}$ & 2006 \\
\hline Miniatitlan & MEX & 0.4 & MDP & 2014 \\
\hline Moca & DOM & 0.2 & MDP & 2012 \\
\hline Mogalakwena & $\mathrm{ZAF}$ & 0.3 & $\begin{array}{l}\text { DMP, } \\
\text { IDP }\end{array}$ & 2012,2014 \\
\hline Molemole & ZAF & 0.1 & $\begin{array}{l}\text { DMP, } \\
\text { IDP }\end{array}$ & 2010,2014 \\
\hline Molina (La) & PER & 0.1 & MDP & 2012 \\
\hline Monclova & MEX & 0.2 & MP & 2012 \\
\hline St. James-Montego Bay & JAM & 0.1 & PAS & 2015 \\
\hline Moretele & ZAF & 0.2 & IDP & 2015 \\
\hline Moses Kotane & ZAF & 0.2 & IDP & 2014 \\
\hline Muntinlupa & PHL & 0.5 & $\mathrm{R}$ & 2014 \\
\hline Muriaé & BRA & 0.1 & RR & 2010 \\
\hline Mysore & IND & 0.9 & CDP & 2006 \\
\hline Naga & PHI & 0.2 & $\mathrm{E}$ & 2013 \\
\hline Nampula & MOZ & 0.5 & M & 2015 \\
\hline Nanded & IND & 0.4 & MP & 2006 \\
\hline Natal & BRZ & 0.8 & MP, RR & 2007,2008 \\
\hline Natitingou & BEN & 0.1 & MDP & 2004 \\
\hline Navojoa & MEX & 0.2 & MDP & 2016 \\
\hline Neiva & $\mathrm{COL}$ & 0.3 & MP & 2009 \\
\hline Ngaoundere & CMR & 0.2 & MDP & 2014 \\
\hline Niamey1 & NER & 0.2 & MDP & 2012 \\
\hline Niamey4 & NER & 0.1 & MDP & 2014 \\
\hline Niamey 5 & NER & 0.1 & MDP & 2013 \\
\hline
\end{tabular}


Table 10.11 (continued)

\begin{tabular}{|c|c|c|c|c|}
\hline City & $\begin{array}{l}\text { Country ISO } \\
3166-1\end{array}$ & $\begin{array}{l}\text { Population } \\
\text { million }\end{array}$ & Plan type & Year \\
\hline Nicosia & CYP & 0.1 & M & 2014 \\
\hline Niteroi & BRA & 0.5 & MP & 2004 \\
\hline Noumea & NCL & 0.1 & MP & 2014 \\
\hline Nova Iguaçu & BRA & 0.8 & MP & 2008 \\
\hline Nueva Laredo & MEX & 0.4 & MDP & 2014 \\
\hline Ocaña & $\mathrm{COL}$ & 0.1 & RR & 2012 \\
\hline Odessa & USA & 0.1 & $\mathrm{CP}$ & $2008,11,15$ \\
\hline Olinda & BRA & 0.4 & RRP & 2004 \\
\hline Ouahigouya & BFA & 0.1 & MDP & 2009 \\
\hline Ouessé & BEN & 0.1 & MDP & 2011 \\
\hline Palmas & BRA & 0.3 & PAS & 2015 \\
\hline Palmira & $\mathrm{COL}$ & 0.3 & E, RR & 2012 \\
\hline Panama & PAN & 0.9 & PAS & 2015 \\
\hline Parakou & BEN & 0.2 & MDP & 2007 \\
\hline Pembroke Pines, FL & USA & 0.2 & $\mathrm{CP}$ & 2013 \\
\hline Peoria & USA & 0.2 & \begin{tabular}{|l} 
E, SAP, \\
GP \\
\end{tabular} & $\begin{array}{l}2003,2009, \\
2013\end{array}$ \\
\hline Pereira & $\mathrm{COL}$ & 0.5 & $\begin{array}{l}\text { MDP, } \\
\text { PAS }\end{array}$ & 2012,15 \\
\hline Petrolina & BRA & 0.3 & MP & 2006 \\
\hline Petropolis & BRA & 0.3 & $\mathrm{RR}$ & 2007 \\
\hline Piedecusta & $\mathrm{COL}$ & 0.1 & MDP & 2016 \\
\hline Piedras Negras & MEX & 0.2 & MDP & 2014 \\
\hline Pissila & BFA & 0.1 & MDP & 2008 \\
\hline Piura & PER & 0.4 & MDP & 2014 \\
\hline Polokwane & ZAF & 0.6 & $\begin{array}{l}\text { IDP, } \\
\text { DMP }\end{array}$ & 2012,2013 \\
\hline Popayan & $\mathrm{COL}$ & 0.3 & MDP & 2016 \\
\hline Porto Novo & BEN & 0.3 & MDP & 2005 \\
\hline Porto Viejo & $\mathrm{ECU}$ & 0.3 & $\mathrm{E}$ & 2008 \\
\hline Poza Rica & MEX & 0.2 & MDP & 2014 \\
\hline Puerto Cortés & HND & 0.1 & MDP & 2013 \\
\hline Quibdó & $\mathrm{COL}$ & 0.1 & RR & 2012 \\
\hline Qiunghai & $\mathrm{CHN}$ & 0.5 & $\mathrm{E}$ & 2015 \\
\hline Rajpur Sonarpur & IND & 0.3 & DP & 2007 \\
\hline Ranchi & IND & 0.8 & MDP & 2016 \\
\hline Ratlam & IND & 0.3 & CDP & 2010 \\
\hline Ratlou & ZAF & 0.1 & IDP & 2016 \\
\hline Resende & BRA & 0.1 & $\mathrm{E}$ & 2014 \\
\hline Reynosa Tamaulipas & MEX & 0.6 & MDP & 2012 \\
\hline
\end{tabular}


Table 10.11 (continued)

\begin{tabular}{|c|c|c|c|c|}
\hline City & $\begin{array}{l}\text { Country ISO } \\
3166-1\end{array}$ & $\begin{array}{l}\text { Population } \\
\text { million }\end{array}$ & Plan type & Year \\
\hline Ribeirão das Neves & BRA & 0.3 & RR & 2009 \\
\hline Rio Branco & BRA & 0.4 & $\mathrm{E}$ & 2016 \\
\hline Rio Hacha & $\mathrm{COL}$ & 0.2 & MDP & 2011 \\
\hline Rourkela & IND & 0.3 & MDP & 2015 \\
\hline Rustenburg & ZAR & 0.5 & IDP & 2012 \\
\hline Saint Louis du Nord & HTI & 0.1 & MDP & 2012 \\
\hline Saint Marc & HTI & 0.2 & MIP & 2011 \\
\hline Saltillo & MEX & 0.7 & MDP & 2014 \\
\hline San Andrés de Tumaco & $\mathrm{COL}$ & 0.2 & E & 2004 \\
\hline San Diego & VEN & 0.1 & MDP & 2014 \\
\hline San Felipe Puerto Plata & DOM & 0.2 & RRP & 2013 \\
\hline San José & CRI & 0.3 & MDP & 2012 \\
\hline San José de Cucuta & $\mathrm{COL}$ & 0.6 & MP & 2001 \\
\hline San Jose del Monte & PHL & 0.4 & $\mathrm{E}$ & 2014 \\
\hline San Juan Maguana & DOM & 0.2 & MDP & 2012 \\
\hline San Luis Rio Colorado & MEX & 0.2 & MP & 2013 \\
\hline San Pedro Garza Garcia & MEX & 0.1 & MDP & 2012 \\
\hline San Pedro Macorís & DOM & 0.2 & MDP & 2013 \\
\hline San Pedro Sula & HND & 0.5 & MDP & 2015 \\
\hline Santa Ana & SLV & 0.2 & PAS & 2012 \\
\hline Santa Marta & $\mathrm{COL}$ & 0,4 & PAS & 2012 \\
\hline Santiago de los Caballeros & DOM & 0.7 & PAS & 2015 \\
\hline Santiago de Surco & PER & 0.3 & MDP & 2009 \\
\hline Santo Domingo Este & DOM & 0.9 & MDP & 2015 \\
\hline Sanya & $\mathrm{CHN}$ & 0.7 & $\mathrm{E}$ & 2014 \\
\hline São João Meriti & BRA & 0.5 & MP & 2006 \\
\hline Scottsdale & USA & 0.2 & GP & 2014 \\
\hline Sincelejo & $\mathrm{COL}$ & 0.2 & MDP & 2012 \\
\hline Solarpur & IND & 0.9 & MDP & 2015 \\
\hline Soledad & $\mathrm{COL}$ & 0.5 & MDP & 2012 \\
\hline Sol Plaatje & ZAF & 0.2 & IDP & 2012 \\
\hline Sorsogon & PHL & 0.2 & $\mathrm{R}$ & 2010 \\
\hline Sousse & TUN & 0.2 & MDP & 2014 \\
\hline Tacloban & PHL & 0.2 & $\mathrm{RR}$ & 2014 \\
\hline Tacna & PER & 0.2 & $\mathrm{E}$ & 2007 \\
\hline Tanout & NER & 0.1 & MDP & 2005 \\
\hline Tapachula & MEX & 0.2 & MDP & 2005 \\
\hline Tarapoto & PER & 0.1 & MDP & 2012 \\
\hline Taytay & PHL & 0.3 & $\mathrm{R}$ & 2015 \\
\hline
\end{tabular}


Table 10.11 (continued)

\begin{tabular}{|c|c|c|c|c|}
\hline City & \begin{tabular}{|l|} 
Country ISO \\
$3166-1$
\end{tabular} & $\begin{array}{l}\text { Population } \\
\text { million }\end{array}$ & Plan type & Year \\
\hline Tempe & USA & 0.2 & GP & 2013 \\
\hline Tepic & MEX & 03 & MP & 2010 \\
\hline Teresina & BRA & 0.8 & MP & 2015 \\
\hline Triruvananthapuram & IND & 0.8 & MP & 2012 \\
\hline Thulamela & ZAF & 0.6 & $\begin{array}{l}\text { IDP, } \\
\text { DMP }\end{array}$ & 2012, 2013 \\
\hline Tierralta & $\mathrm{COL}$ & 0.1 & RR & 2012 \\
\hline Torreon & MEX & 0.6 & MDP & 2014 \\
\hline Townsville & AUS & 0.2 & A, E, GP & 2013,2015 \\
\hline Trinidad & $\mathrm{COL}$ & & MDP & 2012 \\
\hline Trujillo & PER & 0.8 & MP & 2013 \\
\hline Tswaing & ZAF & 0.1 & IDP & 2014 \\
\hline Tucson & USA & 0.5 & $\mathrm{E}$ & 2014 \\
\hline Tuluá & COL & 0.2 & MP & 2000 \\
\hline Tuxtepec & MEX & 0.1 & MDP & 2011 \\
\hline Tuxtla Gutierrez & MEX & 0.4 & MDP & 2012 \\
\hline Uberlandia & BRA & 0.7 & MP & 2006 \\
\hline Ujjain & IND & 0.5 & MDP & 2010 \\
\hline uMhlabuyalingana & ZAF & 0.2 & IDP & 2016 \\
\hline uPhongolo & ZAF & 0.1 & IDP & 2008 \\
\hline Urapan & MEX & 0.3 & MDP & 2015 \\
\hline Uribia & $\mathrm{COL}$ & 0.1 & MDP & 2012 \\
\hline Valledupar & $\mathrm{COL}$ & 0.4 & PAS & 2015 \\
\hline Veracruz & MEX & 0.6 & MP & 2008 \\
\hline Victoria & MEX & 0.3 & MDP & 2013 \\
\hline Villa Alvarez & MEX & 0.1 & MDP & 2014 \\
\hline Villa el Salvador & PER & 0.4 & MDP & 2001 \\
\hline Villa Hermosa & MEX & 0.6 & MDP & 2012 \\
\hline Villa Maria Triunfo & PER & 0.4 & MDP & 2007 \\
\hline Villavicencio & $\mathrm{COL}$ & 0.4 & MP & 2015 \\
\hline Vitoria (Espirito Santo) & BRA & 0.4 & PAS & 2015 \\
\hline Vitoria da Conquista (Bahia) & BRA & 0.4 & MP & 2006 \\
\hline Warangal & IND & 0.8 & MDP & 2012 \\
\hline Wengcheng Town & $\mathrm{CHN}$ & 0.2 & M & 2015 \\
\hline West Palm Beach & USA & 0.1 & $\mathrm{CP}$ & 2008 \\
\hline Xalapa & MEX & 01 & SAP & 2015 \\
\hline Yaoundé 1 & CMR & 0.3 & MDP & 2012 \\
\hline Yaoundé 6 & CMR & 0.3 & RR & 2014 \\
\hline Yopal & $\mathrm{COL}$ & 0.1 & MP & 2013 \\
\hline Zipaquira & COL & 0.1 & MP & 2003 \\
\hline
\end{tabular}




\section{References}

Alcoforado, M.-J., and A. Matzarakis. 2010. Planning with urban climate in different climatic zones. Geographicalia 57: 5-39.

Anguelowsky, I., and J.A. Carmin. 2011. Something borrowed, everything new: Innovation and institutionalization in urban climate governance. Climate Opinions in Environmental Sustainability 3: 1-7. doi:10.1016/j.cosust.2010.12.017.

Aylett, A. 2014. Progress and challenges in the urban governance of climate change: Results of a global survey. Cambridge, MA: MIT.

Baer, W.C. 1997. General plan evaluation criteria: An approach to making better plans. JAPA 63 (3): 329-344. doi:10.1080/01944369708975926.

Baker, I., A. Peterson, G. Brown, and C. McAlpine. 2012. Local government response to the impacts of climate change: An evaluation of local climate adaptation plans. Landscape and Urban Planning 107: 127-136. doi:10.1016/j.landurbplan.2012.05.009.

Basset, E., and V. Shandas. 2010. Innovation and climate action planning. Perspectives from municipal plans. Journal of the American Planning Association 76 (4): 435-450. doi:10.1080/ 01944363.2010.509703.

Belda, M., E. Holtanová, T. Holenka, and J. Kalvová. 2014. Climate classification revisited: From Köeppen to Trewartha. Climate Research 59 (1): 1-13. doi:10.3354/cr01204.

Buckley, H. 2010. Cities and the governing of climate change. Annual Review of Environment and Resources 35: 229-259. doi:10.1146/annurev-environ-072809-101747.

CAI-Clean air initiative and Cities development initiative for Asia. 2012. Climate Change Plans and Infrastructure in Asian Citis. Pasig city: CAI and CDIA.

CDP-Carbon Disclosure Project. 2014. CDP Cities 2013. Summary Report on 110 Global Cities. London: CDP.

Carmin, J.A., N. Nadkami, and C. Rhie. 2012. Progress and Challenges in Urban Climate Adaptation Planning. Results of a Global Survey. Cambridge, MA: MIT.

Fraser, A., and D.V. Lima. 2012. Regional technical assistance initiative on climate adaptation planning in LAC cities. Survey results report.

Hunt, A., and P. Watkiss. 2011. Climate change impacts and adaptation in cities: A review of the literature. Climatic Change 104 (1): 13-49. doi:10.1007/s10584-010-9975-6.

IPCC-International Panel on Climate Change. 2014. Annex II: Glossary. In Climate change 2014: Synthesis report. Contribution of working groups I, II and III to the fifth assessmeny report of the Intergovernmental panel on climate change, IPCC. Geneva: IPCC.

Lethoko. 2016. Inclusion of climate change strategies in municipal integrated development plans: A case from seven municipalities in Limpopo province, South Africa. Jàmbá-Journal od Disaster Risk Studies 8 (3). doi:10.4102/jamba.v8i3.245.

Norton, R.K. 2008. Using content analysis to evaluate local master plans and zonng codes. Land Use Policy 25: 432-454. doi:10.1016/j.landusepol.2007.10.006.

Preston, B.L., R.M. Westaway, and E.J. Yuen. 2011. Climate adaptation planning in practice: An evaluation of adaptation plans for three developed nations. Mitig Adapt Strateg Glob Change 16: 407-438. doi:10.1007/s11027-010-9270-x.

Revi, A. et al. 2014. Urban areas. In Assessment report 5, IPCC-WGII, 1-113.

Rubel, F., and M. Kottok. 2010. Observed and projected climate shifts 1901-2100 depicted by world maps of the Köppen-Geiger climate classification. Meteorol. Zeitschrift 19 (2): 135-141. doi:10.1127/0941-2948/2010/0430.

Tang, Z., S.D. Brody, C. Quinn, L. Chang, and T. Wei. 2010. Moving from agenda to action: evaluating local climate change actions plans. Journal of Environmental Planning and Management 53 (1): 41-62. doi:10.1080/0964056090339977.

Tiepolo, M., and E. Cristofori. 2016. Climate change characterisation and planning in large tropical and subtropical cities. In Planning to cope with tropical and subtropical climate change, ed. M. Tiepolo, E. Ponte, and E. Cristofori, 6-41. Berlin: De Gruyter Open. doi:10. 1515/9783110480795-003. 
UN-Habitat. 2009. Climate change. The role of cities. Involvement, influence, implementation. UN-Habitat and UNEP-United Nations Environmental Program.

UN-Habitat. 2011. Cities and climate change. Global report on human settlements 2011. London-Washington, DC: Earthscan.

UN-Habitat. 2015. Integrating climate change into city development strategies. Climate change and strategic planning. Nairobi: UN-Habitat.

UNISDR. 2009. 2009 UNISDR terminology on disaster risk reduction. Geneva: UNISDR- United Nations.

Vergara, W. 2005. Adapting to climate change. Lessons learned, work in progress, and proposed next steps for the World Bank in Latin America. The World Bank.

Wamsler, C., E. Brink, and C. Rivera. 2013. Planning for climate change in urban areas: From theory to practice. Journal of Cleaner Production 50 (1): 68-81. doi: 10.1016/j.jclepro.2012. 12.008 .

Wheeler, S.M. 2008. State and municipal climate change plans. Journal of the American Planning Association 74 (4): 482-496. doi:10.1080/01944360802377973.

Open Access This chapter is licensed under the terms of the Creative Commons Attribution 4.0 International License (http://creativecommons.org/licenses/by/4.0/), which permits use, sharing, adaptation, distribution and reproduction in any medium or format, as long as you give appropriate credit to the original author(s) and the source, provide a link to the Creative Commons license and indicate if changes were made.

The images or other third party material in this chapter are included in the chapter's Creative Commons license, unless indicated otherwise in a credit line to the material. If material is not included in the chapter's Creative Commons license and your intended use is not permitted by statutory regulation or exceeds the permitted use, you will need to obtain permission directly from the copyright holder.

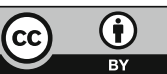

